\title{
A SOCIOLINGUISTIC ANALYSIS OF ADDRESSING TERMS USED IN TANGLED MOVIE MANUSCRIPT
}

\author{
Dian Muhammad Rifai and Sevian Tri Prasetyaningrum \\ Graduate Students of Universitas Sebelas Maret Surakarta \\ anitadianzain@yahoo.co.id
}

\begin{abstract}
This research aims at finding out the kinds of addressing terms manuscript and the reasons of using addressing terms used in Tangled Movie Manuscript. The type of this research is a descriptive qualitative research which takes a document oriented as the method of collecting data. By this method, the researchers uses Tangled movie manuscript as the data source, and the data taken are the expressions which contain addressing terms. The rate of addressing terms use first name is the biggest. The result of the research shows that there are five kinds namely, addressing using name (fist name, full name, and last name), addressing using intimacy, (3) addressing using kinship, (4) addressing using respect, and (5) addressing using mockery. The study find seven reasons of addressing terms used in Tangled movie manuscript were showing solidarity, intimacy, mockery, power, respectful, and anger.
\end{abstract}

Keywords: sociolinguistic, addressing term, speaking

\begin{abstract}
ABSTRAK
Penelitian ini bertujuan untuk menemukan jenis-jenis istilah dalam memanggil dan alasan dari penggunaan istilah dalam memanggil yang digunakan pada naskah film Tangled. Jenis penelitian ini adalah penelitian deskriptif kualitatif yang mengambil data dari dokumen sebagai metode pengambilan data. Peenelitian menggunakan naskah film Tangled sebagai sumber data dan data diambil dari ekspresi yang mengandung istilah dalam memanggil. Istilah dalam panggilan yang paling banyak digunakan diambil dari nama awal. Penelitian ini menunjukkan bahwa terdapat lima jenis istilah panggilan, memanggil menggunakan nama (nama awal, nama lengkap, nama akhir), memanggil menggunakan panggilan akrab (intimacy), memanggil dengan panggilan kekerabatan (kinship), memanggil dengan panggilan hormat (respect), dan memanggil dengan panggilan ejekan. Penelitian ini menemukan tujuh alasan dalam menggunakan istilah panggilan yang digunakan pda naskah film Tangled diantaranya untuk menunjukan keakraban, kemesraan, ejekan, kekuatan, penghormatan, dan kemarahan.
\end{abstract}

Kata kunci: sociolinguistic, istilah dalam memanggil, berbicara

\section{INTRODUCTION}

People use language to communicate each other. As a member of society, people have their own behavior toward language. Sociolinguistics has been defined as the study of language in its social context. The study of language in its social context means crucially the study of linguistic variation. In different social contexts, an individual will speak in different ways. This is called stylistic variation. Moreover, speakers who differ from each other in terms of 
age, gender, social class, ethnic group, for example, will also differ from each other in their utterance the address term, even in the same context - this is called social variation.

Every language shows the social characters of the speaker or addresses. Furthermore, it shows the relation between them. Addressing term is one of the important tools of communication which is used in society. Kinds of basic rules of the addressing terms are social class, age, sex, profession, marital status, politeness and other related aspect. The speaker uses addressing term to call the person who involved in the conversation. The use of addressing term depends on the addresser and addressee's relationship, the social status or individual involve in the conversation, the situation and purpose of the conversation.

Wardaugh (1993:253) confirms that the actual rules of address in a society are as complex as the society itself. Someone may address the same person in different ways. It is due to social context. In addressing, the speaker usually use address terms to call each other during the conversation. The speaker also uses different style in addressing someone. Warding (2000:267) states that one consequence is that choosing the right terms of address to use, in a hierarchical society may not always be easy. He also describe that people may address or names another by title (T), by first name (FN), by last name (LN), by nickname, and even by some combination of these forms. Furthermore, Parkinson (1985:1) address' of term is words used in a speech event that refer to the addressee of that speech event, can be extremely important conveyors of social information.

The aim of addressing is to maintain social relationship between addresser and addressee in society (Artika, 2008:1).Greetings need to be done by both participants to start conversation. Addressing term is the part of greeting. Addressing term in greeting of conversation shows the interest between the participants. Some people usually do addressing someone before they begin the conversation. Calling someone's name is the most common way of addressing. In addressing, the person must consider the classification, such as addressing using name, addressing of intimate terms, addressing of kinship terms, addressing of respectful terms and even addressing of mockeries (Wardaugh, 2000: 264). People can find many forms of addressing term used. In the formal situation, people usually address someone else by their titles like $\mathrm{Mr}$., Mrs., Miss, etc. besides in relax situation someone often calls a friend with his or her nick name such as Joe for Joshua or Cathy for Catherine. Addressing term related to politeness in communication. Each kind of addressing terms has different level in communication process. Being polite is a complicated business in any language (Holmes, 1992: 296).

People should understand the language, social and cultural values of the society. They tend to think of politeness just a matter of saying please in making request and saying thank you when someone does something for us or gives us what we want. Being linguistically polite involves speaking to people appropriately in the light of their relationship to you (Holmes, 1992: 296). People need to understand the social values of a society in order to speak politely. Choose the appropriate addressing terms to call someone can show the politeness level. For example, the sentence "sweet dream, freaks" said by someone to addressing his friend show that the words "freak" has low level of politeness in conversation. In other words it's including impolite addressing terms. From the example above can be a consideration that people should use addressing terms which appropriate to addressing someone and we also considerate politeness in every sentence we said in order not to offends the partner of conversation (Artika, 2008:4).

The phenomena that addressing term can indicate the level of politeness in daily conversation and also represented in this movie therefore it encourages the writer to conduct a research dealing with address terms used in movie manuscript. Besides, the researcher is interested in choosing this topic of the research with consideration that analyzing addressing 
term can be useful to interact with others include in educational process such as between students and teacher, etc. A number of people generally do addressing someone before starting conversation. Calling someone's name is the most common way of addressing. In addressing, Wardaugh (2000: 264) implies that the person must consider of close relationship/ intimateness, addressing of kinship term, addressing of respectful term, and addressing of mockeries.

There are some kinds of English Addressing terms. First, addressing terms using name. In addressing terms using names, the speakers use name to addressing the other e.g. Jack, Elizabeth, Will, etc., Second, addressing terms using kinship. In addressing terms using kinship, the speakers uses the kinship terms that is title without last name (TLN) to address the other e.g. Mom, Dad, Grandma, etc. Third, addressing terms using intimacy. The speakers address the other uses the polite terms to substitute others name in this kind of address terms. e.g.: darling, dear, sweetie, etc. The reason of addressing terms using intimacy is to show intimacy, addressing terms using respect In this kind, the speakers use the title before name to address someone e.g. Mr. Jacob, Mrs. Smith, etc., fourth, addressing terms using mockery, the speaker usually addresses the other by using mockery terms in this kind. e.g.: fool, freak, damn, etc.

A certain type of addressing term brings different kind of reasons. Chika (1982: 46) states that addressing term is often part of greeting. Addressing and greeting can indicate the same meaning that show power and solidarity. The reasons of the addressing term are to show intimacy, power differential, and respect. According to Chika (1982:47), it is quite usual intimacy societies to find the same addressing terms being used both to keep inferior in their place. She also adds that some people used title plus last name to show their respect to other people.

Hymes (1972) in Chaer (2004:48) explains the SPEAKING theory, first, setting and scene. The setting and scene are the places, occasions, or natural situations that can influence the people in choosing an addressing term. People may consider a more formal variety of a language when they talking in an office than when talking in a picnic place. The second one is participants. Participant is all members who join the conversation, can be speaker and hearer, sender and receiver. Social status of the participant influences the language that will use. Third, Ends. Ends related to the purpose of speech or conversation or the goals that a speaker wishes to reach. All speech events and speech acts have an end or a purpose. Sometimes several events shared the same style and are distinguished only by purposes and participants or setting.

The fourth one is act sequence. The act sequence refers to the order of a speech, is it narrative, a conversation, or a talking. A formal speech for example, is set carefully with an opening expression, followed with an introduction, a story before entering the main topic. The fifth is key. The key is referred to the manner, spirit, and feeling of the message wished to be captured within the conversation. It is also referred to the spirit captured in the voice or manner of a speaker. The spirit or the feeling may be sincere, modest, or low. Key is often conventionally ascribed to an example of some other component as its attribute. The sixth is instrumentalities. It is close to the track of language that use, such as oral, written, telegraph, or telephone. Instrumentalities refer to utterance code used, such as language, dialect, and register. The seventh is norm of interaction. The norm of interaction is the contextual custom in using the code, including for example allowance for an interruption, using gestures freely, addressing an audience, eye contacts, distance, asking questions about belief, etc.

The writer also includes the previous studies related to the topic about addressing term to support the recent study. The first research was done by EisNaeni (2011) entitled: "The Sociolinguistics Analysis of Politeness in Addressing Terms Used in "Final Destination 2" Movie Manuscript". The researcher analyzed the address terms in Final Destination 2. The researcher employed the theories such as the notion of address terms, Sociolinguistic, Speaking 
Theory, Politeness, and also Tu and Vous theory is used to analyze the politeness pattern of the use of addressing terms in order to solve the problem statements. The researcher found the reason of employing the address terms includes showing respect, power, intimacy or solidarity, and anger.

The second research was conducted by Asmawati (2003), she discussed about addressing in her research "A Sociolinguistics Analysis on English Address System Used in Blackboy Novel". In her research she found five kinds of address term (1) Address using name, (2) Address using respectful term, (3) Address using family relationship, (4) Address using close relation, and (5) Address using mockery. The third research was conducted by Resita, Fany (2015) entitled "The Sociolinguistic Analysis of Addressing Terms Used in "Karate Kid Movie". The result of this research show that there are five variations of addressing terms such as addressing term using name, kinship, politeness, intimacy, respect, and mockery. Those kinds of addressing terms have some reasons of employing them such as to show intimacy, power/authority, respect, politeness, and anger/ dislike. Politeness pattern of addressing terms used in movie not only used Mutual/ Symmetrical Tu (T) but also Mutual/ Symmetrical Vous V Asymmetrical Tu (T) and Vous (V). Asymmetrical Tu (T) and Vous (V) is still divided into two forms; Giving Vous (V)_Receiving Tu (T) and Giving Tu (T)_Receiving Vous (V) Thus, the researchers are eager to complete the available related research by conducting this research.

The fourth research was conducted by Siti Sulastri (2012). The result of the study show that firstly, the variations of address systems come into 12 types; first name, full name, intimate name, kinship name, solidarity name, mockery name, title, title plus first name, title plus last name, profession, respect and unfamiliar term. Secondly, there are 8 reasons in using address system; showing intimacy, showing anger, showing anxiety, showing mockery, showing power, showing respectful, showing solidarity, showing unfamiliarity. The position of the current study is that the current study has the same purpose with the previous study. The current study wants to analyze the addressing term of the character and the reason of choosing particular addressing term. It is almost the same with the previous study but the current study analyzes the addressing term on different movie. It analyzed the addressing term on Tangled Movie. Thus the writer carries out the study of the sociolinguistics analysis of addressing terms used in tangled movie manuscript. The objective of the study are to find out the kinds of addressing terms used in Tangled Movie manuscript and to find out the reasons of using addressing terms used in Tangled Movie Manuscript.

\section{METHODS}

In doing this research, the researchers used descriptive qualitative research, because the researchers intends to describe the types of address terms and describe the reasons of using each type of address terms used in Tangled movie. The data of the study is expressions that include address terms. The data sources is the Tangled movie manuscript. The researchers used documentation and observation as the method of collecting data in this research. The steps as follows; watching the movie, Noting all the address terms in the Tangled Movie manuscript, retyping all the expressions contain address terms in Tangled movie manuscript, and analyzing the data which contain address terms in Tangled movie manuscript.

The data were be analyzed through descriptive analysis technique. In analyzing the data, the researcher followed the steps; documenting the expressions that include addressing terms, analyzing the types of addressing terms, analyzing the reason of using address terms, and making the conclusion and suggestion based on data analysis. 


\section{FINDINGS AND DISCUSSION}

\section{The Kinds of Addressing Terms}

The kinds of address terms that can be found in Tangled movie manuscript are name, kinship name, intimacy name, respect name, and mockery name.

\section{a. Addressing Terms Using Name}

In this kind of addressing term, the speakers address the other by calling their names. Usually, the speakers use the first name, last name, nick name or family name.

1) First Name

\section{Datum 1.24}

Flynn : Well, I've got to say, didn't know you had that in you back there. That was pretty impressive.

Rapunzel: I know! I know. So, Flynn, where're you from?

Flynn : Whoo-oo! Sorry, blondie, I don't do back-story. However I am becoming very interested in yours. Now I, I know I'm not supposed to mention the hair.

In the dialogue above, Rapunzel addresses his friend named "Flynn". She just calls "Flynn" without its last name. The word "Flynn" is the nick name of Rider in the dialogue above used by Rapunzel to addressing him.

\section{Reason of using addressing term}

As it is described above, Rapunzel is Flynn's friend. They go out together to leave the castle. They help each other with an agreement. Flynn helps Rapunzel to go out from castle and Rapunzel helps him to get a crown. After they introduced their name, they are agree to call the first name. Rapunzel calls his friend "Flynn" and Flynn calls her name "Rapunzel". They have a strong solidarity relationship each other. Based on the theory, addressing term using name can be used to show some purposes. In the dialogue above, Rapunzel addresses his friend named "Flynn". She just calls "Flynn" without its last name. The word "Flynn" is thenick name of Rider in the dialogue above used by Rapunzel to addressing him. In that situation, Rapunzel uses "Flynn" when she wants to know more about Fylnn by making solidaritywith him. The purpose of using addressing term "Flynn" is to show solidarity.

\section{2) Full Name}

\section{Datum 1.16}

Rapunzel : Who are you, and how did you find me?

Flynn : Mm-hm. I know not who you are, nor how I came to find you, but may I just say...i. How yadoin'? The name's Flynn Rider. How's yourday goin'? Huh? Ugh!

Rapunzel : Who else knows my location, Flynn Rider?

Flynn : All right, blondie-

Rapunzel : Rapunzel

Flynn : Gesundheit. Here's the deal 
In the dialogue above, Flynn Rider uses "Flynn Rider" when he introduces himself to Rapunzel and they have not already closed each other. After that, Rapunzel addresses him by using his full name "Flynn Rider".

$\underline{\text { Reason of using addressing term }}$

As it is described before, Flynn introduces himself to his new friend "Rapunzel". Flynn mentions his full name "Flynn Rider". The word "Flynn Rider" is the full name of Rider in the dialogue above used by Flynn Rider to addresshimself. In that situation, Flynn Rider uses "Flynn Rider" when he introduces himself to Rapunzel and they have not already closed each other. Finally, Rapunzel addresses him by using the full name to show solidarity each other. Rapunzel doesn't call with the special name because there is no agreement. Based on the theory, addressing term using full name can show some purposes. The purpose of using addressing term "Flynn Rider" is to show solidarity in introducing.

3) Last Name

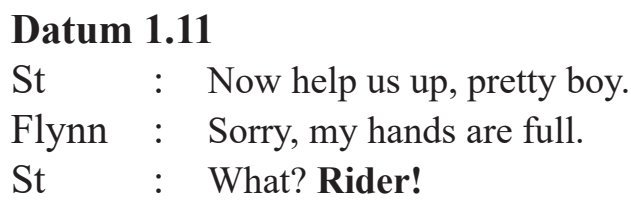

The dialogue above is the dialogue between Stabbington Brother and his friend. In the dialogue above, St (Stabbington Brother) addresses his friend by using last name "Rider" without the full name "Flynn Rider".

\section{$\underline{\text { Reason of using addressing term }}$}

From the data above we can look the example of addressing term using name. It is the way a person calls someone that has higher level than addressee. It makes the Addresser is free to call the addressee without any additional or special name. Stabbington brother and Fylnn meets in the forest. Stabbington brother asks Flynn to help him but Flynn doesn't help. Stabbington and Fylln have known each other previously. Stabbington brother usually calls Flynn with the last name "Rider" to get solidarity. He wants to show solidarity with his friend "Flynn" so that Flynn can help him from a difficult situation. In the dialogue above, St (Stabbington Brother) addresses his friend by using last name "Rider" without the full name "Flynn Rider".

\section{b. Addressing Term using Kinship name.}

In the kind of addressing term, the speaker use the kinship terms to addresses the other. The form of kinship terms is title without last name.

\section{Datum 2.1}

Young Rapunzel : Why can't I go outside?

Gothel : The outside world is a dangerous place, filled with horrible, selfish people. You must stay here, where you're safe. Do you understand, flower?

Young Rapunzel : Yes mommy. 
The dialogue above is the dialogue between Rapunzel and her step mother. Rapunzel must give respect her mother so she may not call the name of her step mother. She call her step mother by saying "mommy". It is the example of kinship name.

\section{Reason of using addressing term}

Gothel and Young Rapunzel are a step mother and a step daughter. Rapunzel is stolen and raised by Gothel as Gothel needs her hair power. Young Rapunzel asks her foster mother the reason why she cannot go outside. Gothel gives explanation why Young Rapunzel cannot go outside. Young rapunzel can understand and agree with Gothel. As can be seen, Young Rapunzel calls Gothel "mommy". Mommy has the same meaning with mother. By mentioning the word "mommy", it means that Young Rapunzel wants to show a sense of decency, affection, and gives respect to his parents. It means that addressing terms using kinship above shows power.

\section{c. Addressing terms using intimacy}

The speakers address the other uses the polite terms to substitute others name in this kind of address terms. e.g.: darling, dear, sweetie, etc. The reason of addressing terms using intimacy is to show intimacy.

\section{Datum 3.2}

Gothel : Uh, Rapunzel! How you manage to do that every single day without fail! It looks absolutely exhausting, darling.

Gothel : Then I don't know why it takes so long! Ergh, ho-ho-ho, darling, I'm just teasing.

Rapunzel : Hmm, hehehe. Alright, so, mother, as you know, tomorrow is a very big day

The dialogue above is the dialogue between Rapunzel and her step mother "Gothel". In that dialogue above, the word" darling" is used by a step mother "Gothel" to make her daughter to be closer with her. It is the example of intimacy term.

\section{$\underline{\text { Reason of using addressing term }}$}

As it is described before, Rapunzel and Gother (her step mother) are mother and daughter who have close relationship. Conversation above takes place while Rapunzel welcomes her step mother but Gothel (her step mother says unkind words to her. It hurts Rapunzel's heart. To make calm, Gothel addresses her daughter by using the word "darling". It can make them very intimate. Based on the theory, if a speaker has a close relationship with the hearer, his or her words of speech can be intimate. In that situation, Gothel uses "darling" to make her daughter to be closer with her. The purpose of using addressing term "darling" is to show intimacy.

\section{d. Addressing terms using respect}

In this kind, the speakers use the title before name to address someone.

\section{Datum 5.1}

Vlad : What about me? I'm broke

Rapunzel : Please, stop

Flynn : We can work this out 


$\begin{array}{lll}\text { Rapunzel } & : & \text { Please, leave him alone } \\ \text { Flynn } & : & \text { Gentlemen, please } \\ \text { Rapunzel } & : & \text { Give me back my guide! }\end{array}$

In the dialogue above, Flynn addresses Vlad who wants to steal his money by using the word "gentlemen". He uses it without mentioning name because he wants to show respect in certain situation.

\section{Reason of using addressing term}

Vlad and his friends want to kill Flynn because he has lost a crown. Rapunzel helps to save Flynn from Vlad and his friends. Flynn addresses Vlad and his friends by using the title "gentlemen" without name. It is uttered miserably. By using the term "gentlemen" to address Vlad and his friends, it means that Flynn shows respect to them for taking pity. Based on the theory, addressing terms using respect can be used to show respect. This dialogue gives the example of reason addressing terms using respect. In this dialogue, the speaker addresses by using respect to show respect.

From the data above we can identify the reasons of addressing term using respect. In the data above we find that to call someone, people can use the addressing term namely gentlemen. This kind of terms is used to show respect.

\section{e. Addressing terms using mockery}

The speaker usually addresses the other by using mockery terms in this kind. e.g.: fool, freak, damn, etc

\section{Datum 5.1}

Flynn : How did you know about her? Tell me, now!

Stabbington Brother : It wasn't us. It was the old lady

Flynn : Old Lady...Agh! Wait! No! Wait! You don't understand, she's in trouble! Wait!

In the dialogue above, Flynn addresses Gothel (the third person) to St by using mockery term "Old lady". It is expressed angrily.

\section{$\underline{\text { Reason of using addressing term }}$}

Flynn talks with a man (Stabbington Brother) in the forest. Stabbington Brother knows about Gothel (Rapunzel's step mother). She is very cruel to her daughter. Flynn knows that Rapunzel has been lied by her step mother. Flynn screams to warn Stabbington Brother so that he tells about Rapunzel's step mother. Flynn is very angry with her. He addresses Rapunzel's step mother by using the term "old lady". It is uttered angrily. By using the term "old lady" to address Rapunzel's step mother, it means that Flynn wants to show his anger to someone. Based on the theory, addressing terms using mockery can be used to show mocking or swearing in bad manner. However, this dialogue gives the other example of reason addressing terms using mockery. In this dialogue, the speaker addresses by using mockery to show anger. 
Table. 1

The Kinds of Address System

\begin{tabular}{clc}
\hline No & \multicolumn{1}{c}{ Address Terms } & $\sum$ \\
\hline & Using Name & 10 \\
1. & First Name (Pascal, Fylnn, Greno, Rapunzel, Eugene, Ulf, & 3 \\
& Guther, Bruiser, Fang, Max) & Full Name (Flynn Rider,Eugene Fitzherbert, Maximus) \\
& Last Name (Rider, Vladimir, Killer) & 3 \\
2. & Kinship Name (mommy, mother, mum,) & 3 \\
3. & Intimacy Name (darling, dear, my flower, sweetheart, my & 6 \\
4. & precious girl, patience boys) & \\
5. & Respect Name (gentlemen) & 1 \\
& Mockery Name (old lady, a bad horse) & 2 \\
\end{tabular}

From the table above, it could be seen that the number of first name was the biggest. It had 10 data of addressing terms using first name. From the table 1 . It was clear that they were 28 data of address terms. They were included 10 data refer to first name, 3.data refer to full name, 3 data refer to last name, 3 data refer to kinship name, 6 data refer to intimacy name, 1 datum refers to respect name, and 2 data refer to mockery name.

Based on the finding above, the researchers concluded that the most of address terms used in Tangled movie is using first name. It could be happened because Tangled movie belong to kind of strained movie.

Table 2.

The Reason of Using Address Terms

\begin{tabular}{clc}
\hline No & \multicolumn{1}{c}{ Reason of Using Address Terms } & $\Sigma$ \\
\hline 1. & Showing solidarity & 16 \\
2. & Showing Intimacy & 10 \\
3. & Showing mockery & 1 \\
4. & Showing power & 8 \\
5. & Showing respectful & 1 \\
6. & Showing anger & 1 \\
& Total & $\mathbf{3 7}$ \\
\hline
\end{tabular}

From the table above, it could be seen the number of the reason of using address term that showing solidarity was the biggest one. It reaches 16 data.From the table, it was clear that they were 37 data the reason of using English address terms. In showing solidarity it included 16 data. 10 data that showing intimacy, 1 datum that showing mockery, 8 data that showing power, 1 datum that showing respectful, and 1 datum that showing anger.

Based on the finding above, the researchers concluded that address terms in Tangled movie was almost showing solidarity 
Table 3.

Kind and reason of uning Addressing Term

\begin{tabular}{|c|c|c|}
\hline No & Address Terms & Reason \\
\hline \multirow{5}{*}{1.} & Using Name & Showing Solidariry \\
\hline & $\begin{array}{l}\text { First Name (Pascal, Fylnn, Greno, Rapunzel, } \\
\text { Eugene, Ulf, Guther, Bruiser, Fang, Max) }\end{array}$ & \\
\hline & & \\
\hline & $\begin{array}{c}\text { Full Name (Flynn Rider,Eugene Fitzherbert, } \\
\text { Maximus) }\end{array}$ & \\
\hline & Last Name (Rider, Vladimir, Killer) & \\
\hline 2. & Kinship Name (mommy, mother, mum,) & Showing power \\
\hline 3. & $\begin{array}{l}\text { Intimacy Name (darling, dear, my flower, } \\
\text { sweetheart, my precious girl, patience boys) }\end{array}$ & Showing intimacy \\
\hline 4. & Respect Name (gentlemen) & Showing respect \\
\hline 5. & Mockery Name (old lady, a bad horse) & $\begin{array}{l}\text { Showing anger, } \\
\text { showing mockery }\end{array}$ \\
\hline
\end{tabular}

This study had shown that there were five kinds of addressing terms used by the characters in Tangled movie: (1) addressing using name (fist name, full name, and last name), (2) addressing using intimacy, (3) addressing using kinship, (4) addressing using respect, and (5) addressing using mockery. The finding showed some pattern in the addressing terms. Some of the findings were in accordance with the previous findings in previous studies but some of the unique addressing terms were also found.

Based on the theory of Wardaugh (2000: 264), he implies that there were five kinds of addressing terms. (1) Address using name, (2) Address using respectful term, (3) Address using family relationship, (4) Address using close relation, and (5) Address using mockery. The addressing terms were used based on their reasons. The reason of address terms usage in Tangled movie manuscript were showing solidarity, showing, intimacy, showing mockery, showing power, showing respectful, and showing anger. Based on the theory of Chika (1982) there were four reasons of using addressing terms namely showing solidarity, respectful, intimacy, and power differential, According to the theory of Wardhaugh (2006), there were four reasons of using addressing terms namely showing intimacy, power, unfamiliarity, and familiarity. It could be argued that more forms of reasons of using addressing terms were actually used in daily life.

If we compare with the previous study, there will be some similarities and differences. From the kind of addressing term the first previous study entitled "The Sociolinguistics Analysis of Politeness in Addressing Terms Used in "Final Destination 2" Movie Manuscript" found that there are five addressing term used in Final Destination 2 Movie Manuscript. They are Addressing term uning name, using Kinship, using Intimacy, using respect, and using mockery. The researcher found the reason of employing the address terms include showing respect, power, intimacy or solidarity, and anger.

The second research entitled the second research was conducted by Asmawati (2003), she discussed about addressing in her research "A Sociolinguistics Analysis on English Address System Used in Blackboy Novel". In her research she found five kinds of address term address using name, address using respectful term, address using family relationship, address using close relation, and address using mocker. Those kinds of addressing terms have also some 
reasons of employing them such as to show intimacy, power/authority, respect,, politeness, and anger/ dislike.

The third research entitled "The Sociolinguistic Analysis Analysis of Addressing Terms Used in "Karate Kid Movie". The result of this research show that there are five variations of addressing terms such as addressing term using name, kinship, politeness, intimacy, respect, and mockery. Those kinds of addressing terms have also some reasons of employing them such as to show intimacy, power/authority, respect, politeness, and anger/ dislike. The fourth research was conducted by SitiSulastri (2012). The result of the study show that firstly, the variations of address systems come into 12 types; first name, full name, intimate name, kinship name, solidarity name, mockery name, title, title plus first name, title plus last name, profession, respect and unfamiliar term. Secondly, there are 8 reasons in using address system; showing intimacy, showing anger, showing anxiety, showing mockery, showing power, showing respectful, showing solidarity, showing unfamiliarity.

From the previous studies above we can conclude that almost all studies found all five addressing term in the previous research. There is only one research that found 12 kind of addressing term. There are almost all research found there are five addressing term used by the characters movie in each research. They are addressing term using name, kinship, politeness, intimacy, respect, and mockery. The four previous studies and the current study also have the same reason of the choice the addressing term. They are as to show intimacy, power/authority, respect,, politeness, and anger/ dislike. On the other hand the last study found that there are eight reasons in using address system. It is natural because every character in each movie has different style. From the discussion above, we can conclude that there are different kinds of addressing term in every single theory from the expert and research. Furthermore, there are also different reason in choosing addressing term in every single theory from the expert and studies. From the all studies, the rate of address system use name is the biggest among other kind of addressing term

\section{CONCLUSION}

After identified and analyzed the data on previous chapters, the researchers found several conclusions. From the data analysis, the researchers found that there are five kinds of addressing terms which are used in Tangled movie manuscript, such as addressing terms using name, using kinship, intimacy, respect and also mockery. The rate of address terms use first name is the biggest. After analyzing kinds of address terms used in Tangled movie, the researchers interprets that the study help the readers to know about the kinds of address terms used in Tangled movie. The researchers find some reasons of employing addressing term used in Tangled movie manuscript. Those reasons are employing addressing terms to show solidarity, intimacy, mockery, power, respectful, and anger. Using the right kind of addressing terms endears one to the people of the society.

One of the earliest studies of sociolinguistics was about the way people address each other. Terms of address are important to communicate effectively and successfully. Each person can use various terms of address to show respect toward other person. Some sociolinguists have become interested in explaining why a person uses different terms of address in different contexts. Some of the teachers use different methods to teach addressing forms. Among different methods, explicit teaching, implicit teaching, reading texts, using context which includes terms of address, using context is directly related to this study. The study of addressing terms can be an authentic material to be taught to the students. The students can understand the kinds of addressing terms and its reasons. The students can try to understand the language used by the community, especially in the application of address terms. 


\section{REFERENCES}

Artika, Ratna P. 2008. An Analysis on the Use of Intimate Address System in the Drama Films (A Sociolinguistics Approach).Unpublished Research Paper. Surakarta: Muhammadiyah University of Surakarta.

Chaika, Elaine. 1982. Language: The Social Mirror. Social Edition. Boston, Massachusetts USA: Heive Publishers.

Holmes, Janet. 1992. An Introduction to Sociolinguistics. London and New York: Longman.

Hudson, Richard Antony. 1980. Sociolinguistics. Cambridge: Cambridge University .

Mills, Sara.2003. Gender and Politeness. United States of America. New York: Cambridge University Press.

Moghaddam, A.S. et all. 2013. The Analysis of Persian Address Terms Based on the Theory of Politeness. SKASE Journal of Theoretical Linguistics. Vol 10, no.3

Naeni, Eis. 2011. The Sociolinguistics Analysis of Politeness in Addressing Terms Used in "Final Destination 2" Movie Manuscript. Salatiga: State Islamic Studies Institute (STAIN) of Salatiga.

Parkinson, Dilworth B. 1985. Constructing the Social Context of Communication: Terms of Address in Egyptian Arabic. New York,NY: Mouton de Gruyter.

Wardhaugh, Ronald. 2006. An Introduction to Sociolinguistics. Massachusetts: Blackwell. 